\title{
最適化過程としてみた土地利用計画
}

\section{LAND USE PLANNING FROM THE VIEWPOINT OF OPTIMIZATION PROCESS}

\author{
槙谷 博 光* \\ By Hiromitsu MAKITANI
}

\begin{abstract}
The purpose of this paper is to develop a method to make rational land use plans, based on computer aided data processing. First, concept of land use planning is defined from the viewpoint of optimization process in order to give logical consistency to land use planning process. Second, a methodology is proposed which can realize logically consistent land use planning based on the above mentioned concept of optimizing process. Then, a computer aided land use planning system is developed which is effective for not only city-wide land use planning such as land use zoning but also microscopic land use planning such as land readjustment.
\end{abstract}

Keywords : land use planning, optimization, computer aided design

\section{1. はじめに}

土地利用計画は，市場メカニズムに必ずしも整合しな い財としての土地の特質に起因して生ずる土地問題に対 する, 非市場的な解決手段として位置ゔけられる.

しかしながら, 都市の土地問題, すなわち都心部での 過密, 郊外部での乱開発やスプロールをみる限り, 現行 制度下での土地利用計画がその役割を十分に発揮してい るとはいいがたい. 上記の問題に対しては, 土地利用計 画の制度的, 政治・政策的, 技術的な諸側面からのアプ ローチがあり得るが, 本研究ではこれらのうち, 技術的 側面に着目する. その問題意識は以下のようである. 従 来自治体において行われてきた計画立案作業では, 手作 業による地図の塗り分けや重ね合わせ等の手法に頼る部 分が多く, 検討し得る代替案はごく少数に限られ, また 十分客観的な判断を下すに足る情報を得ることが困難で あった.そのため, 計画者は常に情報過少な状況のもと での判断を余儀なくされ, 勘に頼ることになる.こうし て出来上がった計画案は市民を十分に説得できるだけの 客観性, 科学性が伴わず, また政治的怨意に対しても無 抵抗なものであったということができる.

\footnotetext{
* 正会員 工博 東京大学助教授 工学部土木工学科 ( ₹113 文京区本郷 7-3-1)
}

そこで，本研究ではコンピュー夕を用いたデー夕解析 を前提として, 十分な客観性, 科学性を有する計画立案 方法を作り上げることを目的とする.

具体的には, 以下の 3 つのアプローチを行う. 第一に, 土地利用計画の論理的一貫性を確保するため, 最適化過 程の概念的枠組に従って土地利用計画の概念整理を行 う. 第二に, 従来の計画立案プロセスを, 最適化という 一貫性のある論理で補強しつつ合理的な計画立案を行う ための方法論を作り上げる. 第三に，ここで提示する方 法論を実行に移すために不可欠なコンピュータ支援シス テムを作成する.

\section{2. 最適化過程としてみた土地利用計画}

ここでは,土地利用計画を最適化過程としてみたとき， それがいかなる構造の問題としてとらえられるか，につ いて明らかにする.

\section{（1）概 念規 定}

従来, 土地利用計画という語の意味するところは必ず しも判然としないが，おおむね次の 3 つの性格がある.

(1) 将来のある時点における土地利用の理想像

(2) 土地利用の法的規制および各種面開発事業

(3) (1)を達成するため(2)の各手段の最適な組合せを時 間的に並べたプログラム 
本研究では,(1)の意味での土地利用計画を主に扱うが, ここでいう理想像の「理想」とは，「都市計画において 目標とされる環境や利便を達成するための総合的な計画 の一環として, 目的を満たし, かつ交通計画, 供給処理 施設計画，公園緑地計画等との整合性を確保すること」 と考える. このように考えると, 土地利用計画の策定に 対し，「規範に従い，関連する主体間の利害の合理的な 調整のもとに，土地利用の望ましい姿を描き出すこと」 という最適化過程としての概念規定を与えることができ る.ここで規範とは, 最も抽象的には社会的厚生を可能 な限り高めることであると規定することができるが，そ の具体的内容は（2）に述べるようにさまざまである.

\section{(2) 計画立案の規範}

土地利用計画の規範とは，計画によって達成しようと する事柄を概念的に述べたものであり，目標あるいは目 的と称されることも多い.

都市計画関連文献 ${ }^{1)}$ で代表的と思われるものの中か

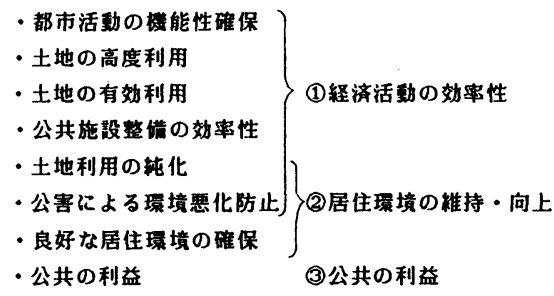

図一1 土地利用計画の規範
ら，都市の土地利用計画の規範についての記述を拾い上 げて整理すると図一1に示すように，(1)経済活動の効率 性, (2)居住環境の維持・向上, (3)公共の利益, の 3 つに 大別される.

もちろんこれらの具体的記述は文献により異なるし， 土地利用の規範的最適化モデル ${ }^{2)}$ (後出, 3. (2)) にお けるように計画の規範というものがより限定された形で 表現される場合もある.

これらの規範を，計画関連主体別の目的関数として整 理したものが表一1である.ここで，計画関連主体とし

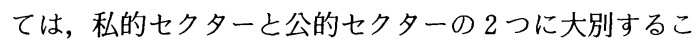
とができる.

私的セクターにおいては，その構成員である私的主体 は自己の私的満足を追求するものとしてとらえることが できるが，ここではこれをさらに都市的利用主体，非都 市的利用主体, 土地所有者の 3 つの夕イプに分けている. 都市生活者はこれらのうちいずれかのカテゴリーに入る わけであるが，同一人物が住宅をもち，農業を営み，か つ土地所有者であるというように, 重複することもある. 公的七クターとしては, 自治体と国に大別できる. 自 治体の立場からの土地利用計画を考える場合, 財政と公 共の福祉が大きな課題であるが，これは同表に示すよう な複数の目的関数によって構成されていると考えられ る.また，一都市を扱う土地利用計画であっても，広域 あるいは国家的見地からの計画が介入する場合もあり得

表一1 都市の土地利用計画にかかわる主体と目的関数

\begin{tabular}{|c|c|c|c|c|c|c|c|}
\hline \multicolumn{3}{|c|}{ 体 } & \multicolumn{2}{|c|}{ 䘽 点 } & 最適化すべき目的関数 & 㖕溇の可否 & 指挒 \\
\hline \multirow{6}{*}{ 私的 } & \multirow{3}{*}{$\begin{array}{l}\text { 都市的 } \\
\text { 利用主体 }\end{array}$} & 住宅 & \multicolumn{2}{|c|}{ 立地効用 } & 效 用 & 0 & 資産圙値 \\
\hline & & 工業 & \multicolumn{2}{|c|}{ 立地効用 } & 利唡 & 0 & 資座価値 \\
\hline & & 商笨 & \multicolumn{2}{|c|}{ 立地効用 } & 利 洞 & $\mathrm{O}$ & 資産価値 \\
\hline & $\begin{array}{l}\text { 非都市的 } \\
\text { 利用主体 }\end{array}$ & 患林藥 & \multicolumn{2}{|c|}{ 生 活 } & 生活の安定 & $x$ & - \\
\hline & \multirow{2}{*}{\multicolumn{2}{|c|}{ 土地所有者 }} & \multirow{2}{*}{\multicolumn{2}{|c|}{ 土地からの収益 }} & キャビタルゲイン & \multirow{2}{*}{$\mathrm{O}$} & \multirow{2}{*}{ 資座価优 } \\
\hline & & & & & インカムゲィン & & \\
\hline & \multirow{10}{*}{ 自治件 } & & \multirow{2}{*}{ 財 政 } & \multirow{2}{*}{ 期政余剿 } & 土地閔速䣲収 & 0 & 盗座価檤 \\
\hline & & & & & 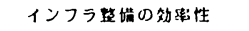 & $\mathrm{O}$ & 利用者当りコスト \\
\hline & & & \multirow{8}{*}{$\begin{array}{r}\text { 公垬の } \\
\text { 福祉 }\end{array}$} & $\begin{array}{l}\text { 盗源利用の } \\
\text { 效军性 }\end{array}$ & 笞 効 用 & $\mathrm{O}$ & 䓡資産価檤 \\
\hline & & & & \multirow{2}{*}{$\begin{array}{l}\text { 酒利用の } \\
\text { 公平性 }\end{array}$} & 土地公源の公平な分配 & $\mathrm{O}$ & $* 1$ \\
\hline & & & & & 䑙市サーヒス利用の栰均等 & 0 & $* 2$ \\
\hline & & & & 文通のP消化 & 交道所用時湖の烃弱 & 0 & 䓡交道时湖 \\
\hline & & & & 䍝 境 & 良好な居住境境の䧳保 & $x$ & - \\
\hline & & & & 防 災 & 災䨐からの安全性 & $x$ & - \\
\hline & & & & 希少算源の & 非地の保全 & $x$ & - \\
\hline & & & & & 自然・文化勛の保全 & $x$ & - \\
\hline & 家 & & 上音 & 「公共の福祉」 & に関する項目で、広域あるいい & 国家的的数点 & に立つもの. \\
\hline
\end{tabular}


る.

\section{（3）計画立案の制約条件}

土地利用計画の制約条件としては，大きく分けて資源 的制約，他の計画との調整，土地利用の構想・方針があ る.

\section{a）資源的制約}

まず，新規土地需要量という観点からみると，無秩序 な市街化による弊害を防ぐため, 新規に開発すべき土地 は必要最小限, すなわち計画目標年までに見込まれる土 地需要量に合致すべきであるという制約条件が導かれ る.

次に, 新規に開発可能な土地という観点からみると, 物理的に開発不可能な土地と法的な開発規制が制約とな る.

また，土地を都市的に利用するためには，私的な個人 による投資だけでなく,公共投資が伴わねばならないが， 新規に市街地を拡大しようとする場合，この財政負担が 大きな制約となることもある.

b）他の計画との調整

都市計画は, 競合・重複する都市の土地利用を調整す るところに，その存在理由があるといえるが，これを確 保するために，都市計画法では都市計画相互の調整およ び他の計画との調整に関して定めを置いている.

ここでは，他の計画との調整についてみることにする が，これには都市計画法 13 条における「上位計画等と の調整」と，同法 7 条および 23 条に示される「農林漁 業との調整」がある.

c）土地利用の構想・方針

現実の土地利用計画立案においては, 「都市の核」「都 市発展軸」といったように, 特定の土地の利用をある方 向に導くことを要請する方針が立てられることがある。

この種の構想・方針は, 都市形態論的な視点からのもの であって,（2）で述べた規範と異なり, 都市全体の福 祉の増進に直接結びつけて論じる性格のものではない。 したがって，ここではこれらを計画立案の制約条件と考 え，それが都市全体の土地利用に及ぼす影響を，(2) の規範に対応する評価関数によって評価してその是非を 検討すべきものと位置づける.

\section{（4）解としての土地利用計画}

土地利用計画という語は, 計画を策定する行為および 計画の中で決めている事柄（図面・図書も含む）という 2 つの意味で用いられているが, 本研究の視点からみる と, 前者は最適化の過程を示し, 後者は最適化の解を指 すものと考えられる.（2）でレビューした都市計画関 連文献において, 後者の意味で「土地利用計画」とよば れるものを拾い上げると図一2に示すようなものがあ る.これらのうち, (5) (8)は地区計画に関するもので,
本研究では直接の対象とはしない。そこで(1) (4)につい てみると，(1)は将来のある時点における土地利用像を, その量的側面について述べたものであると考えられる. 一方(2) (4)は上記の将来像を実現するための具体的な規 制・事業である。ここで個別の事業はその対象とする地 理的範囲は小さく, 局地的な環境改善手法であると考え られる.したがって本研究で主な対象とする都市規模で の土地利用計画において求めるべき解は, 土地利用の理 想像およびそれを実現するための用途指定（市街化区 域・市街化調整区域の区分および地域地区指定を以下で はこのようによぶ）であるといえる.

\section{(5) 最適化の概念モデル}

以上に整理した最適化の基本的枠組に従い，土地利用 計画の最適化問題を, きわめて概念的にではあるがモデ ル化して記述すると以下のようになる.

土地利用計画において求めるべき解は，（4）におい て整理したように将来の土地利用の理想像と, それを実 現するための用途指定である. 前者は（2）に整理した ような複数の目的を満足すべき将来の土地利用配置を定 めるマスタープランレベルでの土地利用計画であり, 後 者はこれを可能な限り忠実に実現することを目的として 策定される法定土地利用計画である. したがって, 用途 指定を最終的なアウトプットと考えた場合, 土地利用計 画には 2 段階の最適化過程があると考えられる.

まず，マスタープランレベルでの土地利用計画につい て考える.ここで求めようとする解は住宅, 商業, 工業 といった活動単位での土地利用配置である.このとき土 地利用の地理的最小単位をどうとるかは場合によって異 なるが，ここでは通常の土地取引における最小単位とし ての画地とする。 いま, 対象地域に画地 $1, \cdots, p$ がある とした場合，おのおのの土地は住宅，商業，工業等に利 用されているが, 土地利用が $m$ 種あるとすると, 対象 地域の土地利用は図一 3 のようなマトリクス $x$ で表わ すことができる.

そこで, 最適化問題は,

$$
\operatorname{maximize} \boldsymbol{f}(\boldsymbol{x})=\left[f_{1}(\boldsymbol{x}), \cdots, f_{n}(\boldsymbol{x})\right]
$$

subject to $x \in C$

と表現できる.ここに, $f_{1}(\boldsymbol{x}), \cdots, f_{n}(\boldsymbol{x})$ は（2）に おいて整理した各個別の目的関数である. 実行可能領域

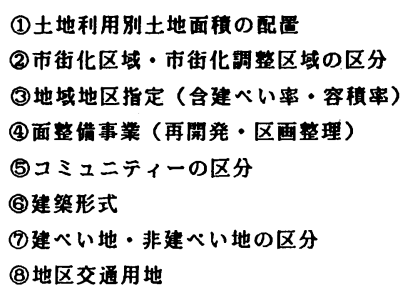

図一2 解としての土地利用計画 


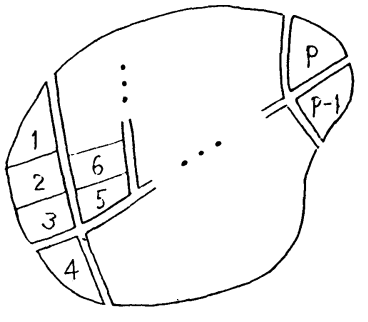

$(1,2, \cdots, P$ 酒地番号 $)$

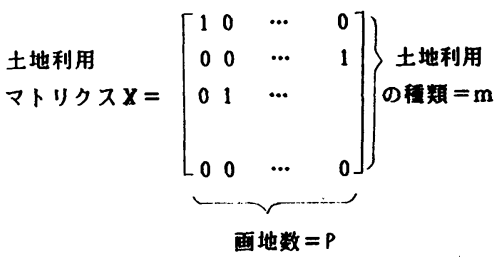

図一3画地と土地利用マトリクス

Cは（3）において整理した制約条件によって規定さ れるが，これには大きく分けて土地の諸条件に基づく物 理的あるいは法的な開発制約と土地利用の将来フレーム との 2 種類がある.

土地 $i(i=1, \cdots, p)$ の自然的, 社会的, 経済的諸条 件は $\boldsymbol{u}_{i}=\left(u_{i}^{1}, \cdots, u_{i}^{r}\right)$ と表わすことができる.ここに， $u_{i}^{1}, \cdots, u_{i}^{r}$ は地形, 交通利便性, 地価, $\cdots$ 等の指標值で ある.この $\boldsymbol{u}_{i}$ に対し，（3）において整理したような各

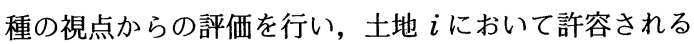

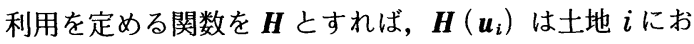
いてあり得る土地利用の集合である。したがって対象地 域全体について, $\boldsymbol{U}=\left(\boldsymbol{u}_{1}, \cdots, \boldsymbol{u}_{\boldsymbol{p}}\right)$ とすれば, $\boldsymbol{H}(\boldsymbol{U})$ は土地 $1, \cdots, p$ において許される土地利用の組合せを示 すが，これは最適化の解 $\boldsymbol{x}$ のとり得る範囲を規定する．

次に各土地の面積を要素とするべクトルを $\boldsymbol{s}=\left(s_{1}\right.$, $\left.\cdots, s_{p}\right)$ とすれば, $\boldsymbol{x} \cdot \boldsymbol{s}$ は $m$ 次ベクトルとなり，その 各要素は土地利用ごとの合計面積を表わす．そこで，土 地利用の将来フレームを $\boldsymbol{D}=\left(d_{1}, \cdots, d_{m}\right)$ とすれば, 最適解 $\boldsymbol{x}$ は $\boldsymbol{x} \cdot \boldsymbol{s}=\boldsymbol{D}$ を満たさねばならない。これを満 たす $\boldsymbol{x}$ の集合を $\boldsymbol{V}$ で表わす.

したがって, 実行可能領域 $\boldsymbol{C}$ は, 上記の $\boldsymbol{H}(\boldsymbol{U}), \boldsymbol{V}$ の積集合として,

$$
\boldsymbol{C}=\boldsymbol{H}(\boldsymbol{U}) \cap \boldsymbol{V}
$$

\section{と表現できる.}

次に第 2 段階の用途指定計画の最適化問題を考える. ここで解とするものは, 用途地域 $1, \cdots, q$ ごとの用途指 定 $\boldsymbol{y}=\left(y_{1}, y_{2}, \cdots, y_{q}\right)$ である.ここに $y_{1}, y_{2}, \cdots$ 等はそ れぞれ一種住専地域, 二種住専地域，…等を表わす．用 途指定の評価関数は，そこで意図されている土地利用の 実現可能性を評価するものである．すなわち，用途指定 $\boldsymbol{y}$ のもとで実現されるであろう土地利用と第 1 段階での 最適解 $\boldsymbol{x}$ との類似度を $g(\boldsymbol{y})$ で表わすことにすると, 最適化問題は,

maximize $g(\boldsymbol{y})$

subject to $\boldsymbol{y} \in \boldsymbol{C}^{\prime}$

と定式化することができる.ここで実行可能領域 $C^{\prime}$ は, 用途指定としてとり得る組合せの集合であるが，これは 用途指定基準に準拠して計画者が経験的判断によって決 めるものである.

\section{3. 最適化過程としてみた土地利用関連分析手 法の位置づけ}

ここでは，4. における計画立案方法論構築の準備段 階として, 最適化過程の枠組のもとに, 従来の土地利用 関連分析手法の位置づけを行う.

\section{(1) 土地分級}

土地分級は，土地の規範的な評価手法を総称したもの であるが4)，土地利用計画における最適化過程の枠組に おいては, 実行可能領域の限定のための手法として位置 ゔけることができる.ここでいう実行可能領域の限定と は，計画における種々の制約条件を満足するか否かの評 価により，解としての土地利用配置のあり得る組合せを 限定することを意味するが，土地分級は 2.（5）の概 念モデルにおける $\boldsymbol{C}=\boldsymbol{H}(\boldsymbol{U}) \cap \boldsymbol{V}$ の $\boldsymbol{H}(\boldsymbol{U})$ に相当す る.

具体的には，ある土地を都市的利用として開発するこ との適否を規範的に判定することであるが，この適否の 判定には種々の視点があり, (1)自然や景観の保全, (2)農 地保全, (3)災害危険性, (4)開発コスト,の4つが代表的 である1).

\section{（2）土地利用の規範的最適化モデル}

土地利用モデルは，大きく分けて立地予測モデルと最 適化モデルに分かれるが，後者はある視点から土地利用 を評価した場合の最適解を求めることを目的とするもの である。

これらのモデルは，そこで前提とされている目的関数 および制約条件の範囲内においては, 数学的に最適性を 保障された厳密な解としての土地利用配置を与えること ができる. しかしながらこれらのモデルでは, 数理計画 問題を解くということに重点が置かれているため，そこ で考慮される要因は定量的なものに限られ，また目的関 数や制約条件も極端に単純化される.すなわち，2（5） の概念モデルにおいて, $\boldsymbol{f}(\boldsymbol{x})$ の代わりにたとえば $f_{1}$ $(\boldsymbol{x})$ をとり, $\boldsymbol{c} \subset \boldsymbol{C}$ なる実行可能領域 $\boldsymbol{c}$ のもとでの最 適解を求めることに相当する.

したがって, 従来の最適化モデルによる解は, 特定の 視点からの, しかも非常に限定された側面のみについて 
得られた極端な解であり，それをそのまま土地利用計画 として採用することはできないが, 第一次近似解として の意義は認㧹ると考えられる.

\section{（3）影響 分析}

「公共計画の効果・影響分析」などというときの「影響」 とは, 多くの場合環境への影響を指す. 従来, 計画の影 響分析といえば個別のプロジェクトが周辺環境に及ぼす 影響のアセスメントを意味する場合がほとんどであり， 都市レベルでの土地利用計画に対してはそもそも影響分 析という概念が希薄であったということができる.

2.において, 最適化の枠組に従って土地利用計画を 整理したが，そこではまず計画の規範として, 複数の主 体について多様な目的関数が存在することを示した。こ のような多目的最適化問題の一般的解法としては，何ら かの実行可能解から出発し, 順次解を改善していくとい う方法がとられる．すなわち，2.（5) の概念モデルに おいて, $x$ を仮定し, $\frac{\partial f_{1}}{\partial x}, \frac{\partial f_{2}}{\partial x}, \cdots$ の值に基づき, 目的 関数の值を改善する方向に $x$ を変更するものである. これは, ある目的関数值の変化が他の目的関数值に与え る影響をチェックすることに相当する．さらに，たとえ ば土地利用の構想・方針のように，定量的な目的関数と して設定しにくいものは，これを制約条件としておき， その影響分析によって是非を評価するという扱いが必要 となる．このように，最適化過程として土地利用計画を 扱う場合, 影響分析は重要な役割を担うものである.

\section{（4）立地予測モデル}

立地予測モデルは, 従来, 交通施設整備を主としたプ ロジェクトの結果生ずる土地利用変化をシミュレートす る目的で開発されてきだ).ここでは，都市レベルでの 土地利用計画という観点から，立地予測モデルの位置づ けについて考える.

まず土地利用計画においては，都市の将来的な人口・ 経済フレームとして, 住宅, 商業, 工業等の活動別の新 規立地需要を求める (2.（5）における $\boldsymbol{V}$ を決定する ことに相当する）必要があるが，従来の実務において多 く用いられている単純なトレンド分析では，たとえば計 画目標時までの間に交通施設整備が行われるような場 合，それによる土地利用変化は予測し得ない．現在の立 地予測モデルでは市町村単位での立地量の予測が可能で あるので，このようなプロジェクト予定地域において， 将来の人口・経済フレームを設定するための有力な手法 として位置づけることができる.

立地モデルの果たし得るいま 1 つの役割として, 土地 利用計画の実現可能性評価が考えられる. 土地利用計画 においては, 将来の土地利用の姿を描いただけであって, それが実現される保証はない，西独のように土地利用計 画の実現を強力に推進する制度的裏付けをもたないわが
表一2 最適化過程における土地利用関連分析手法の位置づけ

\begin{tabular}{|c|c|c|c|}
\hline \multirow[b]{3}{*}{ 第 } & 最通化問题 & \multicolumn{2}{|c|}{$\underset{\text { mabject to }}{\operatorname{maximize}} \boldsymbol{f}(x)=\{\mathrm{f} 1(x), \cdots, f n(x)\}$} \\
\hline & 最通化通罣 & 概念モテルによる表現 & 用いる手法 \\
\hline & $\begin{array}{l}\text { 荑可能领域 } \\
\text { の限定 }\end{array}$ & $C=H(U) \cap V$ & $\begin{array}{l}\text { II }(U) ： \text { 土地分极 } \\
\text { V : 立地予测モテル }\end{array}$ \\
\hline 1 & 代智案作成 & $\begin{array}{l}\text { 部分最通化 } \\
\text { maximize f } 1(x) \\
\text { subject to } x \in C \subset C\end{array}$ & $\begin{array}{l}\text { 土地利用の規範的 } \\
\text { 最通化モデル }\end{array}$ \\
\hline 段 & 泙洒 & $f(x)$ & - \\
\hline 階 & 冢の改善 & $\begin{array}{l}\frac{\partial \mathrm{f} I}{\partial x}, \cdots, \frac{\partial \mathrm{f} n}{\partial x} \text { の唒により、目的 } \\
\text { 闌数が改善される方に } \mathrm{x} \text { を变更 }\end{array}$ & 影繁分析 \\
\hline \multirow{3}{*}{ 第 } & \multicolumn{3}{|c|}{$\begin{array}{ll}\text { 最通化問題 } & \begin{array}{l}\text { maximize } \\
\text { subject to }\end{array}(y), C^{\prime}\end{array}$} \\
\hline & 最通化過程 & 概念モテルルによる表現 & 用いる手法 \\
\hline & $\begin{array}{l}\text { 実行可能領 } \\
\text { の限定 }\end{array}$ & $c^{\prime}$ & $\begin{array}{l}\text { ※用途指定基淮に基 } \\
\text { つき叶画者の経雅 } \\
\text { 的判断により没定 }\end{array}$ \\
\hline 段 & 代智案作成 & $y$ & 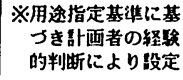 \\
\hline \multirow[t]{2}{*}{ 階 } & 垀洒 & $g(y)$ & 立地予测モデル \\
\hline & 案の改善 & $\begin{array}{l}\frac{\partial g}{\partial y} \text { の值により、目的阔数か } \\
\text { 改䇾される方向にyを㸚更 }\end{array}$ & 影箘分析 \\
\hline
\end{tabular}

国においては, 計画評価の一側面として, 土地利用計画 の実現可能性を予測・評価しておく必要があると考えら れる.これは2.（5）において，最終アウトプットと しての用途指定 $\boldsymbol{y}$ の評価関数 $g(\boldsymbol{y})$ を与えることに相 当する.

2. において示した最適化の過程における（1)〜 (4) の各手法の役割を示したものが表一2である.

\section{4. システム分析的土地利用計画の方法}

本研究では, 土地利用計画を一貫した論理のもとに作 成するため, 最適化過程という論理的枠組で土地利用計 画をとらえることとし，2. においてその概念整理を行っ た.

しかしながら 2.（5）において概念モデルの形で定 式化した最適化問題をそのまま数理計画問題として解く ということは次の理由によりきわめて困難であると考え られる. まず第一に，個別の目的関数 $f_{1}(x), \cdots, f_{n}(x)$ の数 $n$ がきわめて大きい，すなわち，2．（2）におけ る私的主体の目的関数は, 厳密には主体の数だけ存在す ることになる．第二に， $f_{1}(x), f_{2}(x), \cdots$ 等は，効用や 時間，安全性といったさまざまな概念で表現されるもの であり,これらを統一的な尺度で扱うことは困難である. 第三に, 生活の安定や災害からの安全性等定量化が不可 能な目的関数の存在がある.

以上より，土地利用計画を厳密な数理計画モデルとし て扱うことは困難であるといえるが，それでもなお最適 
化という論理の枠組で土地利用計画を扱うためには，人 間の判断を適宜介在させたシステム分析プロセスを組み 立てる必要がある. すなわち，前提条件の設定 $\rightarrow$ 計画案 の作成 $\rightarrow$ 案の評価之改善という一連の作業を循環的に繰 り返しながら, 第一次計画案, 第二次計画案, …としだ いに計画案をより望ましいものに改善するもので, $\mathrm{Chapin}^{5)}$ や土井ら ${ }^{6)}$ の提唱する漸進的アプローチに同じ 考え方である.すなわち，まず主要な目的関数（たとえ ば $\left.f_{1}(\boldsymbol{x})\right)$ を最大化するような解 $\boldsymbol{x}$ を求める.このと き他の目的関数は全く考慮されないか, あるいは一定値 が仮定される. 次にこれらのうちでも優先度の高い目的 関数（たとえば $\left.f_{2}(x)\right)$ が可能な限り大きくなるように $x$ を微調整する.このとき $f_{2}(x)$ の変化に対する $f_{1}(x)$ の変化を感度分析的にチェックしつつ, 望ましい解 $\boldsymbol{x}$ に改善する. 以下 $f_{3}(\boldsymbol{x}) \cdots$ についても同様の操作を繰 り返す. いくつの目的関数までこのような扱いをするか は地域特性や計画立案の基本方針によって異なるが，操 作上は同じである.
本研究では, 都市規模での土地利用計画 (マスタープ ランレベルおよび法定計画レベル）を中心とするが, 地 区単位での局地的な土地利用計画（面開発事業計画レべ ル）についても計画立案の方法を作成している. また， これらを実際に行ううえでは膨大な土地デー夕を効率的 に処理することが不可欠となるが，これを支援するため のコンピュータシステムの開発を行っている.

\section{(1) 都市の土地利用計画}

前項で述べた漸進的アプローチの具体的な形として, 本研究では図一4 のフロー図に示すような計画策定プロ セスを組み立てる.

a) 前提条件の設定

まず，土地利用現況，社会・経済フレーム，各種施設 整備計画，法規制等，土地利用計画立案において前提と なる諸条件を整理する．これらに基づいて，2（5）の 概念モデルにおける $\boldsymbol{f}(x), \boldsymbol{H}(\boldsymbol{U}), \boldsymbol{V}$ 等の具体的な形 が決まる.

b）実行可能領域の限定

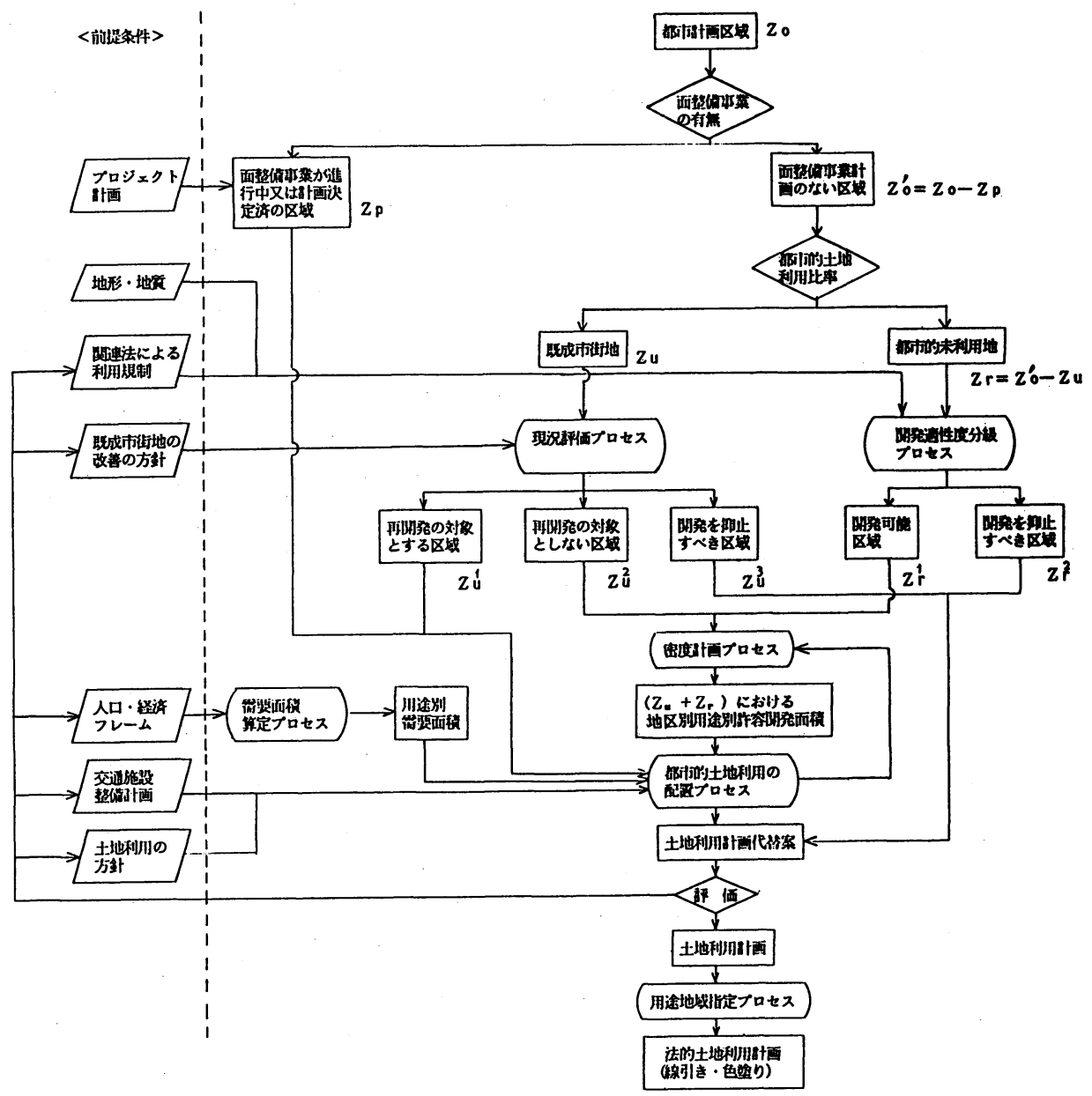


次に最適解の存在し得る範囲としての実行可能領域 $C$ ，すなわち新規に土地利用を配置することのできる区 域およびその土地利用の組合せを可能な限り限定してお くことが必要となるが, $\boldsymbol{C}=\boldsymbol{H}(\boldsymbol{U}) \cap \boldsymbol{V}$ における $\boldsymbol{V}$ に ついては通常社会・経済フレームより与えられるので, $\boldsymbol{H}(\boldsymbol{U})$ が問題になる. 本研究ではこの $\boldsymbol{H}(\boldsymbol{U})$ の限定 を次の 2 段階に分けて行う.

まず, 第一段階として, 計画対象地域（すなわち都市 計画区域) $\left(Z_{0}\right)$ のうちで, 再開発等の面整備事業が進 行中または計画決定ずみの区域 $\left(Z_{p}\right)$ とそうでない区 域 $\left(Z_{0}^{\prime}\right)$ に二分する.これは, 前者においては事業によっ て意図された土地利用がそのまま実現する確度がきわめ て高いため，そのような土地利用をあらかじめ前提とし ておいてもよいとの考え方に基づくものである.

第二段階として, 前段階において「面開発事業計画な し」と分類された土地について, 現況での都市的土地利 用比率に基づいて既成市街地 $\left(Z_{u}\right)$ と都市的未利用地 $\left(Z_{r}\right)$ に二分する.これは, 前者では既成市街地の問 題点解決が主な課題であり, 後者では新規の土地利用配 置が主な課題であることに基づく，そして前者について は, 居住環境面を中心とした現況評価により, 今後の開 発を抑止すべき区域 $\left(Z_{u}^{3}\right)$, 再開発の対象とする区域 $\left(Z_{u}^{1}\right)$, それ以外 $\left(Z_{u}^{2}\right)$, の 3 つの区域に分類する。一 方後者については, 物理的開発可能性および法的規制に 関する分級により, 開発可能区域 $\left(Z_{r}^{1}\right)$ と開発を抑止 すべき区域 $\left(Z_{r}^{2}\right)$ に分類する.

こうして得られた $Z_{u}^{2}$ および $Z_{r}^{1}$ によって実行可能領 域 $\boldsymbol{H}(\boldsymbol{U})$ の地理的範囲が限定される.

c) 代替案の作成

第一次案作成段階では, 地域全体としての土地利用の 効率性という視点から，2（2）で整理した目的関数の うち, 土地利用主体が土地から得る効用の総和を目的関 数 $f_{1}(x)$ とし，これを最大化することを考える.ここ で効用とは, 居住者が得る満足度や企業が得る利益を総 称したものであるが，このような意味での効用は一定の 条件のもとで資産価值に転移することが知られているか $ら^{7)}$, ここでは効用の指標として資産価値評価額を用い ている，具体的には，次に述べるような不動産鑑定評価 法による標準地比較方式を援用した資産価值評価関数を 設定した。

標準地比較方式とは標準地（地価 $=P_{0}$ ) との比較に よって当該地 $(i)$ の地価 $\left(P_{i}\right)$ を評価するもので,

$$
P_{i}=P_{0}\left(1+\alpha_{i}^{1}\right)\left(1+\alpha_{i}^{2}\right) \cdots\left(1+\alpha_{i}^{m}\right)
$$

と表わされる.ここで $\alpha_{i}^{1}, \cdots, \alpha_{i}^{m}$ は標準地と当該地につ いて, 地価形成要因の評価値を比較することによって得 られる係数で,「土地価格比準表」に標準的な值が示さ れている.
したがって, 土地 $i$ を住宅地, 商業地, 工業地として 評価したときの地価を $P_{i}^{R}, P_{i}^{c}, P_{i}^{l}$ とすると, 目的関数 $f_{1}(x)$ は対象地域全域にわたる資産価值を合計した値 であるから，

$$
f_{1}(x)=\sum\left(\delta_{i R} P_{i}^{R}+\delta_{i c} P_{i}^{c}+\delta_{i l} P_{i}^{l}\right)
$$

ただし $\delta_{i R}=\left\{\begin{array}{l}1: \text { 土地 } i \text { が住宅として利用されているとき } \\ 0: \text { れ以外のとき }\end{array}\right.$

$$
\delta_{i c}, \delta_{i l} \text { についても同様 }
$$

と表わされる. そこで, $\boldsymbol{x} \in \boldsymbol{C}(=\boldsymbol{H}(\boldsymbol{U}) \cap \boldsymbol{V})$ を満たし, かつこの $f_{1}(x)$ を最大にするような土地利用配置 $x$ が 求めるものである.

このような $x$ を求めるための手法として, 本研究で は, ある定量的表現が可能な特定の視点に限って一次元 的な目的関数を設定し, これを数理計画問題として解く ための土地利用の規範的最適化モデルを作成してい る3).

\section{d) 案の改善}

上で作成した第一次案は，土地資源利用の効率性とい う観点のみからみた最適化であった。したがって第 2, 第 $3, \cdots$ 目的関数についても可能な限りの改善を行う ことが必要である.ここでは公平性の視点から, 個別の 土地利用主体ごとの効用をみる.すなわち, 第一次案に おいては総効用は最大化されているが, 一部のものが著 しい不効用を受けているという状況が生じ得る.このよ うな不効用は具体的には, 工業地や幹線道路, 鉄道に隣 接する地区での環境悪化が主であると考えられるが，こ れは c) において効用の尺度として設定した資産価値評 価式を用いて計測可能である.

そこで, まず, 資産価值評価式における工業地への接 近性評価値，および鉄道・幹線道路への接近性評価値の 低下（すなわち不効用）の度合を, 支援システムを用い てグラフィック出力する. そして, 不効用が著しいと判 断される主体 $(k)$ については, グラフィック画面上で 土地利用計画の部分変更を行う.このとき, 解 $x$ の変 更による総効用への影響 $\frac{\partial f_{1}}{\partial x}$ を評価しつつ, 主体 $k$ の 効用 $w_{k}(\boldsymbol{x})$ がより大きくなるように解 $\boldsymbol{x}$ を改善する. これ以外の目的関数についても同様の操作を行えばよ い.

一方，これまでのような定量的な扱いが困難な側面か らのチェックも必要である. すなわち, 実際の土地利用 計画立案においては, 全体としての土地利用パターンと しての「おさまり」や「バランス」が議論される。しか しながら,これらは定量指標による扱いだけでは不十分 であり, また機械的操作のみによる処理は困難である. そこで本研究ではこれらの視点からの検討は, グラ フィック出力をみながら画面上で修正を加えるという方 法によっている. 
e）法定土地利用計画の作成

上で得られた土地利用配置 $x$ に基づいて, 法定土地 利用計画としての用途地域指定図を作成する.

2.（5）の概念モデルで示したように，用途指定代替 案 $\boldsymbol{y}$ の実行可能領域 $\boldsymbol{C}^{\prime}$ は, 用途地域指定基準によるが, 同基準においては「性状」「形態」「規模」「相隣」の 各項目について考慮すべきことが定められている．しか し，ここで定めている子細な項目をすべて満足する $\boldsymbol{y}$ を一度に求めようとすれば, きわめて複雑なプロセスと ならざるを得ず，操作上の観点から望ましくない，そこ で, 本研究では, まず用途地域の決定における最重点項 目である土地利用の「性状」において列挙されている基 準に従った簡単な分級アルゴリズムを作成して $\boldsymbol{y}$ の第 一次代替案を作成する.

次にこの第一次案に対し，「形態」「規模」，および「相 隣」等にある諸規定に基づいて $\boldsymbol{y} \in \boldsymbol{C}^{\prime}$ となるように $\boldsymbol{y}$ の修正を行う.ここで11「形態」からのチェックとして は, 指定区域の整形性および路線的指定に関する制限,

(2)「規模」からのチェックとしては，指定区域の最小面 積, (3)「相隣」からのチェックとしては, 住専系地域と 工業系, 商業系地域との近接制限がある. これらの修正 は人間がグラフィック画面をみながら行うのが最も簡便 かつ確実であるから，計算機支援システムにおいて，こ のようなヒューリスティックな処理を可能ならしめてい る.

用途指定は，こうして求めた $\boldsymbol{y}$ に対し，意図された 土地利用の実現可能性評価 $g(\boldsymbol{y})$ を行い, これを最大 とするように $\boldsymbol{y}$ を改善するという最適化過程によって 本来決められるべきであるが, 立地予測モデルの現状か らみて $g(\boldsymbol{y})$ の適切な評価は困難であるので, 本研究 でもここまでの最適化は行っていない.

\section{（2）土地区画整理計画}

本研究では, 局地的土地利用計画のうちでも特に土地 区画整理計画について，その支援システムを作成した.

土地区画整理事業計画は，おおむ水次の手順に従って 進められる.

(1) 対象地区の現況調査により, 問題点を明らかにし, 整備課題を整理するとともに, 計画立案に際して考慮す べき前提条件を整理する.

(2) 上の整備課題と前提条件をもとに, 市街地整備の 基本方針を明らかにする (基本構想).

(3) 土地利用，道路網，供給処理施設等に関する計画 を立案し(概略設計), 加えて事業採算の見通しを立て る (事業計画).

(4) 上の案について地権者の同意を得た後, 都市計画 決定する.

(5) 個別の土地の換地設計を行うとともに，具体的な
工事計画を立てる.

ここで(3)の概略設計および(5の換地設計においては, 設計作業と帳票作成が行われるが，設計作業においては 地理的デー夕に関して，帳票作成においては権利関係 デー夕に関して，それぞれ膨大なデー夕処理を行わねば ならない。このうち後者についてはほとんざ機械化され ているのに対し, 前者は相変わらず手作業に頼る部分が 大きいため, 十分説得力のある計画を立案し得ないばか りか, 地権者にとっても平均減歩率のような抽象的な情 報しか与えられず，これが合意形成を手間取らせる一因 にもなっている.

そこで, 本研究では, 合理的な計画立案のため, これ らの作業を支援するためのシステムを作成した ${ }^{8)}$. その 概略フローを図一5に示す。

まず概略設計の段階では, 設計条件としての平均減歩 率と代替計画案としての幹線街路を入力し, 画面上での

[ 略没计]

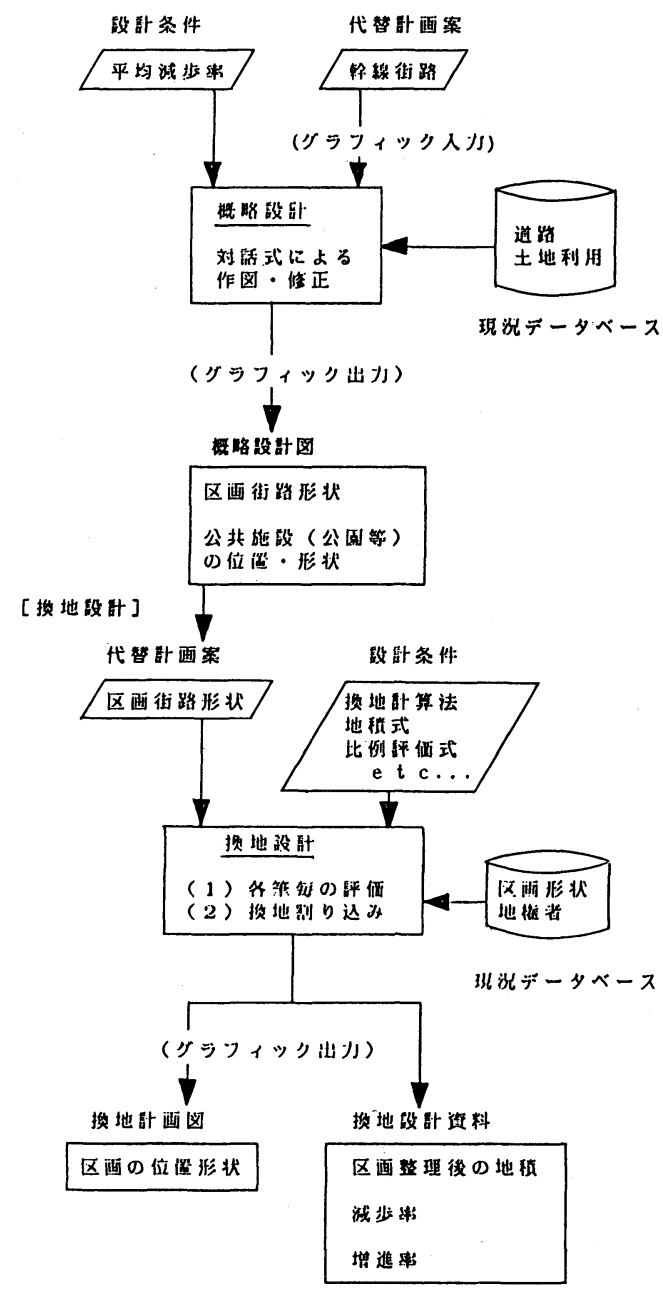

図一5 区画整理設計のフロー 
対話形式による作図・修正によって区画街路形状や公 園, 学校等の公共施設の配置を示す概略設計図を作成す る.

次にこれを前提とし，設計条件としての換地計算法を 指定することにより, 各筆ごとの評価およびそれに基づ く換地割り込みを行うが, 従来この換地割り込みの設計 作業は設計者の主観的判断に委水られていた。しかしな がら, 計画案の説得力をより高めるためには, 明確な規 範に従い, 論理的に一貫したプロセスで案を作成するこ とが必要である.このときの規範としては, (1)現位置主 義の立場から, 換地前後の土地の移動距離を全体として 最小化する, (2)区画整理による効果としての資産価値上 昇を全体として最大化する，あるいは(1)，(2)の折束型な よ゙さまざまなものが考えられるが，本研究ではこれらの 規範に従った目的関数を設定し，これを解くことにより 換地計画案を作成するための支援システムを開発した。 実際の換地計画においては, 地形的制約や基盤施設の将 来計画等の制約条件が存在し，また地権者の意向のよう な定量化が困難な要因も考慮する必要があるので, 上記 の最適化問題を厳密な数理計画問題として扱うことはで きない.したがって支援システムでは最適值の方向へ解 を逐次改善してゆくというアプローチをとるが, その途 中段階での解はそれぞれ計画代替案としての意味を有し ているのであり，それらをわかりやすい形で提示するこ とによって合意形成の支援が可能になる.

\section{5. 適用性の検討}

本研究において作成した計画立案方法の適用性をみる ため，A市のデー夕を用い，4.において提案した方法 論に従い, 支援システムを用いて土地利用計画の作成を 行った。基礎となるデータとしては国土地理院作成によ る細密数值情報を用いている. 計画目標は昭和 70 年と し, 人口, 商業販売額, 工業出荷額の将来值はトレンド 分析により求め,これらを面積に換算するための原単位 は昭和 59 年時点の值を用いた。

写真一1 は, 上記の前提のもとに, 本研究の方法で作 成した土地利用計画の画像出力の一例であるが, これを 現行土地利用計画 (写真一2) と比較してみる.

まず, 現行計画では市街化区域となっているが本研究 の計画案では市街化調整区域となっている地区をいくつ か指摘することができる．これらの地区は，現状におい ても農地が多く，また交通条件等をみても市街化のポテ ンシャルはあまり高くないと考えられ, 本研究の計画案 はこれらの地区の逆線引き(市街化区域を市街化調整区 域に指定変更すること）を示唆するものといえよう．こ れとは逆に, 現行計画では市街化調整区域となっている が本研究の計画案では市街化区域となっている地区があ

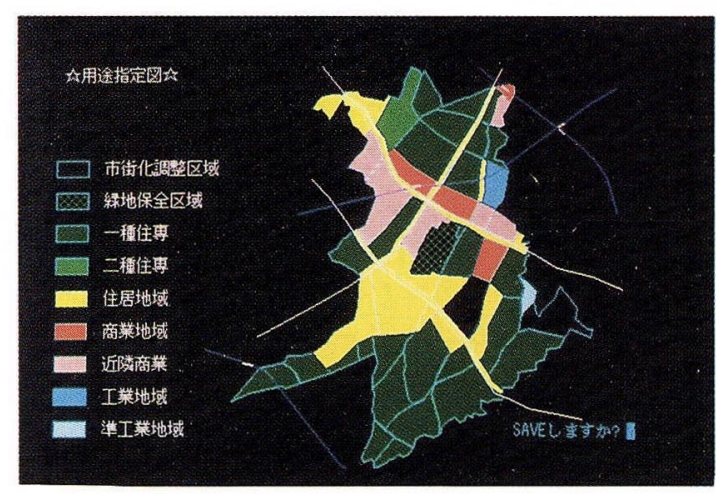

写真一1 支援システムにより作成した土地利用計画の例

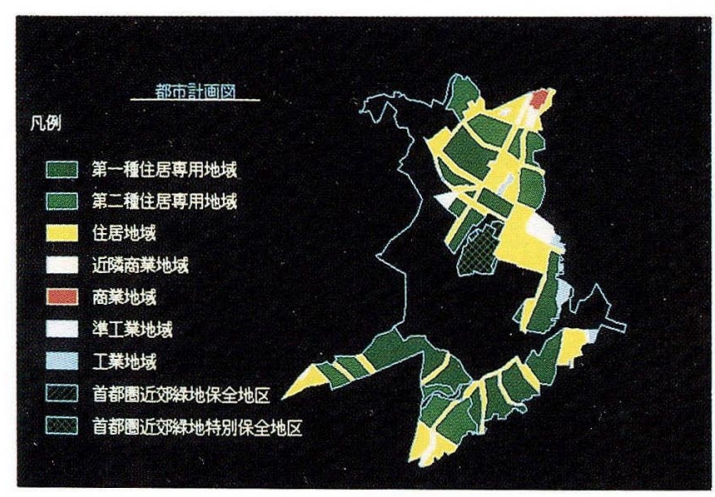

写真一2 現行土地利用計画

る.これらの地区は，現状においてすでに都市的利用が かなりなされており，また交通条件等からみても今後の 市街化のポテンシャルが高いと考えられる.したがって これらの地区については, 本研究の計画案にあるように 市街化区域に組み入れる必要性が高い之判断される.

以上に述べたように, 本研究による計画案によって, 現行計画の問題点をさまざまな角度から検討することが できる.

\section{6. 結 び}

本研究の成果は, 以下の（1)（4）のようにまとめ ることができる.

（1）最適化過程の論理的枠組を用いて土地利用計画 の概念整理を行った.

（2）土地利用計画の立案を, 実用性を考虑しつつ, なおかつ最適化過程の論理に従って行うため, システム 分析的な方法論を構築した.

（3）上記の方法を支援する計算機システムを作成し た.

（4）実際問題への適用により，本研究で作り上げた 方法論および支援システムを用いて，客観的デー夕に基 
づき，論理的一貫性のあるプロセスによって土地利用計 画代替案を作成し，十分実用可能な形で表示することが できることを確認した.

本研究を行うにあたり，東京大学中村英夫教授には， 研究テーマの設定から基本的枠組の構成, さらには個別 の方法論に至るまで, 終始ご指導いただいた。ここに記 して深甚なる謝意を表する次第である.

東京工業大学肥田野登助教授には, 多大な時間を割 いて頂き, 数々の貴重なご示唆を賜ったことを記し, 心 より感謝の意を表する.

また，東京工業大学中村良夫教授，渡辺貴介教授， 森地 茂教授, 東京大学宮本和明助教授の各先生方か らも有益なコメントを頂戴した.記して謝意を表したい.

\section{参 考 文 献}

1）たとえば, 今野 博：都市計画, 森北土木工学全書, 森 北出版, 1981.
(このほかにも多数ある（文献 1 ）参照)

2）槇谷博光・肥田野登: 都市近郊地域における土地利用の 最適配置モデル, 都市計画学会論文集, No. 20, 1985.

3）槙谷博光：土地分級（中村英夫編著, 国土調查, 新体系 土木工学 50$)$, 技報堂出版, 1984 .

4）立地モデルに関する文献は数多いが, 青山吉隆 : 土地利 用モデルの歴史と概念, 土木学会論文集, No. 347, 1984 においてよくレビューされている.

5) Chapin, F.S. and Kaiser, E.I. : Urban Land Use Planning, 3 rd Ed., University of Illinois Press, 1979.

6）土井幸平, ほか：都市計画, 新建築学体系 16 , 彰国社, 1981.

7) Starrett, A. : Land value capitalization in local public finance, Journal of Political Economy, Vol.89, pp. 306 -327, 1981.

8）横谷博光, ほか：土地区画整理事業計画支援システム, 土木学会第 42 回年次学術講演会講演概要集, 1987 (投稿 中).

（1987.8.7 - 受付） 